\title{
DEPENDENCE OF PROPERTY INCOMES AND SOCIAL CONTRIBUTIONS AS INDICATORS OF AGRO-BUDGETARY POLICY MANAGEMENT
}

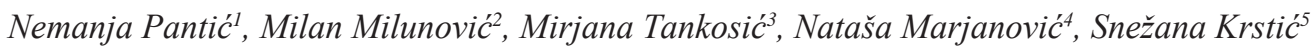

*Corresponding authorE-mail: milunmil68@gmail.com

A R T I C L E I N F O
Original Article
Received: 28 July 2018
Accepted: 29 August 2018
doi:10.5937/ekoPolj1903707P
UDC 332.021:338.43

Keywords:

agro-budget policy, property incomes, social contributions.

JEL: H20, H21, H50, H62

\begin{abstract}
A B S T R A C T
Agro-budget policy is the basic lever of modern fiscal theory. For this reason, it is scientifically challenging for all market economies, but also for countries in transition. Agro-budget deficits and amounts of public debts faced by many countries requires orientation on this policy. Harmonization of economic policies, inter alia, tax rates, is a necessity but difficulties in its realization are numerous. Numerous authors emphasize its necessity, but also the need to investigate the correlation of categories of government revenues. This article is based on determining the dependence between property incomes and social contributions and the obtained results will confirm or reject hypotheses. In addition, obtained results will show the degree of development of budget policy and thus agrobudget policy and leave space for future authors to find appropriate measures and instruments in future researches for achieving basic macroeconomic goals.
\end{abstract}

(C) 2019 EA. All rights reserved.

\section{Introduction}

A modern fiscal theory based on the disadvantages of the previous theories made the synthesis in order to remove them. That implies a synthesis of public revenues and public expenditures. This would stabilize the economy of one country, while the

1 Nemanja Pantić, University of Kragujevac, Faculty for hotel management and tourism in Vrnjačka Banja, Vojvođanska 5A, 36210 Vrnjačka Banja, The Republic of Serbia, +381 36 51500 24, E-mail: nemanja.pantic@kg.ac.rs, ORCID ID: 0000-0003-0030-6950

2 Milan Milunović, PhD., Assistant Professor, Budget Department, Ministry of Defense, Birčaninova 5, 11000 Belgrade, Serbia, milunmil68@gmail.com. ORCID ID: 0000-0002-4975-9742

3 Mirjana Tankosić, PhD, Assistant Professor, Faculty of Business Studies, Megatrend University, Bulevar maršala Tolbuhina 8, 11000 Belgrade, mtankosic@megatrend.edu.rs. ORCID ID: 0000-0002-4983-9762

4 Nataša Marjanović, PhD., Assistant Professor, High Business School of Vocational Studies, Gradski park 2, 11000 Belgrade, natasa.marjanovic@hotmail.com ORCID ID: 0000-0002-4986-9683

5 Snežana Krstić, PhD, Associate Professor, Military Academy, Pavla Jurišića Šturma 33, 11000 Belgrade, Serbia, snezanakrstic17@gmail.com. ORCID ID: 0000-0001-3642-6985 
synthesis of fiscal and monetary policy measures, on the other hand, would create the driving force of the economic growth. In the center of modern fiscal policy is agricultural budget policy, with its impact on all agroeconomic sub-systems, should lead to a balance in the economy. (Auerbach, 2000). Full employment and full use of capacities in order to prevent cumulative depression and unemployment should be enabled by an active agro-budget policy (Dimitrijevic, 2018). Modern countries are facing budgetary dysfunctions due to a reduction of fiscal revenues and the growth of public expenditures. Growth of the public expenditures is faster than the growth rate of gross domestic product (Harjula, 2007). Macroeconomic agricultural budget policy is scientifically challenging for all market economies, including countries in transition. Finding an optimal revenue management model and budgetary expenditures implies the creation of appropriate instruments that can be applied in order to achieve macroeconomic stability goals. This implies the harmonization of agricultural budgetary policies to create a unique macroeconomic space. The ultimate goal is to create a free market that will allow freedom of movement of goods, money, labor and capital. The research of measures and instruments of budgetary policy in developing countries must reveal a functional link between budget policy and within agro budget policy and elements of macroeconomic stability (budget deficit, public debt, public spending, aggregate supply and demand, etc.) (Milojević, et al., 2012). Another important reason for budget policy orientation lies in the fact that there are evident conflicts of objectives: to suppress unemployment at the cost of inflation and balance of payments deficit or to reduce inflation with unemployment and declining production (Horne \& Wachowicz, 2007; Mićović \& Miletić, 2019). Special attention should be given to the property incomes that, due to its share in total revenues, is often marginalized (Nearing, 2019).

Tax control and their management is an important element of fiscal policy (Lind \& Nordlund, 2019). Taxes and related tax revenues are important part of the fiscal system. For this reason, there is also a need of harmonization the national tax systems of the states towards common goals (Grover, 2018). The idea of the necessity of harmonizing tax structures was created in the 1980's, so it is necessary to take appropriate measures for their harmonization (Neumann, 1986). This is highlighted in the Eurozone where certain legal frameworks have been adopted and they are binding on the member states in accordance with the legislation of the European Union (Sekera, 2018). These changes include the competition of tax systems to create the conditions of tax-legal convergence. It is basically about the process of unification and integration of the tax systems of the member states. There are sectors that are lagging behind in development. In order for the economic development it is necessary to harmonize public expenditures in accordance with the objectives of macroeconomic policy. In addition to public expenditures, harmonization and public revenues are necessary (Kovačević et al., 2019). In the periods of crisis, the role of budgetary policy is especially emphasized (Vukša et al., 2015; Milojević, \& Mihajlović, 2019). Budgetary policy coherence has significant positive effects on the labor market (Popescu, et al., 2018). Developing of information systems has also big importance in providing a base for new workplaces (Neary, 2018). Large corporations are the major generator of workplaces in modern economy (Nica, 2018). Innovation and 
education have a positive impact not only on tourism development but also on the overall economic development of a country. (Radovanović \& Rendulić, 2017).

Tax harmonization gives significant results that are reflected in the equalization of value added tax (VAT), or their specific variants. However, for more than twenty years there have been no changes in direct taxes harmonization. Reasons should be search in, first of all, reducing the possibility of independent tax policy operations. Numerous authors emphasizes the necessity of harmonizing tax rates, as well as examining the coherence and dependence of certain tax revenues, which would have policy measures having a multiplier effect.

The limitation of the public sector that began to make significant problems and significantly burdens the budgets of the states have big importance (Fatima, 2012). Space should be given to private capital that will be motivated for investment in the crucial sectors of the economy. The best mechanism to motivate private equity holders to invest their capital is to decrease interest rates (Pedauga et al., 2018).

Social transfers are increasingly burdening the budgets of those countries that are confronted with a significant unemployment rate. Even social transfers in the expansion and high employment in order of compensation for increased cost of living lead to the pressure of social budget expenditures.

Numerous authors emphasize the necessity of harmonizing tax rates at all levels, as well as the necessity of examining the dependence between categories of government revenues (Benito et al., 2017). Based on their suggestions, the analysis of the correlation between the categories of government revenues will show the degree of interconnection, and thus the development of measures and instruments of budgetary policy. The accent is on state revenues and their complex structure. Components of government revenues includes taxes, social contributions, revenues from public goods and property income (Baum, et al., 2013). Taxation ranging, from 45.8\% in Slovakia to $87.6 \%$ in Denmark, has a dominant share in total revenues. In other EU member states they are moving within these borders and have average share of about $60 \%$ of total state revenues.

The next category of total share of government revenue is related to the social contributions that are after taxes the most significant source of total revenues. Fluctuations are much higher than in the case of taxes, because in Denmark they are only $0.9 \%$, in Sweden $3.3 \%$ and in Iceland 3.5\%. In other EU member states they are moving from $4.3 \%$ in Ireland to $16.8 \%$ in the Czech Republic. The diversity in the participation of social contributions clearly indicates the insufficiently harmonized structure of social contributions and its rates in the European Union. Likewise, the energy paradigm plays a major role in achieving the sustainable development of modern economies (Andrei, J. V., et al., 2017).

Including all categories of government revenues, property incomes has the least share, so fluctuations for this category are the least. In Hungary, for example, property incomes participates with only $0.8 \%$ of total revenues compared to Iceland, where is the highest share of this category from $5.8 \%$. 
Differences in the share of various types of government revenues, as well as the recommendations of numerous authors had an impact in conceiving the topic of this paper. Using of statistical methods will be tested the dependence of property incomes and social contributions. The set hypotheses will serve to make adequate conclusions. Necessary measures and instruments for improving the real situation can be the subject of future analysis and recommendations for authors dealing with this topic.

\section{Literature review}

Williams (2019) was talking about the significance of property incomes and particulary how it was collected. At the same time, he criticized the lack of awareness of the significance of this revenue in total revenues and its effects on GDP. He also pointed out insufficient research on the connection of property incomes and other types of government incomes, but also of expenditures whose analysis could lead to significant conclusions that could be implemented in macroeconomic policy measures in order to achieve significant results.

Sinclaire (2014), apart from the significance of property incomes similar to Williams, points to the different rules of taxation of property that are not compatible, making it more complicated for property income issues. He also noted that significant progress was not made in terms of property incomes in the period 1995-2014. It is clear that there is a need for more significant activities in relation to these revenues and their connection with other sources of revenues and expenditures.

Chao \& Eden (2002) emphasized the great importance of property incomes and related taxes. The reason is that these revenues are an important source of local government revenues and source of financing the significant projects. For this reason, they need to be further explored especially their connection to other sources of revenues and expenditures.

Anderson \& Shimul (2018) have considered property incomes over the past 45 years and their elasticity and resistance on changes in tax policies. The significance of their research is in the stabilization of the economic system faced with fluctuations. They emphasized the inefficiency of examining the connection with certain forms of expenditures, which would make the measures adopted by the policy more effective and more detailed.

Goudswaard \& Caminada (2015) pointed out the concern caused by the economic effects of high labor costs. According to them, the nature of social contributions is of exceptional importance and the changes in the method of payment will lead to a changes in the perception of employers who will regard these contributions as a price rather than as a tax. Their research is limited to OECD member countries. The conclusion is that $2 / 3$ of these contributions are paid by employees and $1 / 3$ by employers. Thus, social state should be reformed. Also, examining the relationship between various categories of government revenues can make the measures of the adopted policy more efficient, which should be the subject of further researches. 
Ooghe et al. (2003) evaluated the impact of social contributions on employees' salaries and came to the conclusion that more than $50 \%$ of these contributions are borne by employees. Also, it was concluded that if the pension level is to be maintained in the future period, it will be necessary to increase the contribution rates which, according to some authors, is unsustainable in the long period. In addition to other conclusions, it is important to to determine the potential correlation between categories of government revenues. After that must be adopted appropriate tax policy measures that will strengthen macroeconomic stability.

Ramić \& Mešanović (2017) point out that taxes of property and social contributions are not harmonized and that there are no legal regulations that would harmonize these two types of taxes as direct tax revenues. This necessitates not only the harmonization of these tax rates, but also the determination of the links between these revenues and the adoption of additional measures of macroeconomic policy in order to achieve its basic objectives.

Ross (2004) gives a description of the administrative arrangements for the collection of social contributions at the international level, with a special focus on pension funds. The aim is to identify critical issues and to establish a necessary of the government approach in resolving these issues as a required condition in the implementation of reforms. It was concluded that the system of collecting social contributions is different in different parts of the world and thus is not harmonized. The need for harmonization in the world is accompanied by the necessity of harmonizing not only social contributions, but also other state revenues and thus property incomes.

Pop (2016) pointed out that social contributions are one of the most important tax revenues and that the reform of the tax system must accept the importance of social contributions to economic development. Romania's integration into the European Union did not have a positive impact on social contributions. The integration itself has increased the number of employees and businesses development, but there is no shifts in social contributions, and the correlation with other tax revenues (among other with property incomes) is not determined, which is a brake of faster economic progress. Social contributions have increased, but their structure, with the aforementioned shortcomings, should reveal the measures that need to be implemented in development policy. Shang et al., (2018) analyzed effect of within-household relative income on happiness, taking into account the role of gender identity.

\section{Research methodology}

For the purposes of testing the dependence of property incomes and social contributions we used the software package SPSS within Chi squared test. The reasons for this type of analysis are explained in the introduction and refer to the recommendations of numerous authors in the literature review. Used data is downloaded from Eurostat and will be presented in the next part of the discussion of the results. 
In theoretical considerations, the following models are used:

$X$ - Property incomes

$Y-$ Social contributions

Set of values of variable $X: R(X)=\left\{A_{1} \ldots, A_{1}\right\}$

Set of values of variable $Y: R(Y)=\left\{b_{1}, \ldots, \mathrm{b}_{s}\right\}$

Set of values of variable $(X, Y): R[(X, Y)]=\left\{\left(\Theta_{i}, b_{j}\right): 1 \leq i \leq r, 1 \leq j \leq s\right\}$ $f_{i j}$ : the frequency of $\left(a_{i} ; b_{j}\right)$ in the sample

$f_{i}$ : (marginal) frequency of $a_{i}$ in the sample

$g_{j}$ : (marginal) frequency of $b_{j}$ in the sample

$f i=\sum_{j=1}^{s} f i j \quad g j=\sum_{i=1}^{r} f i j$

$p_{i j}=P\left(X=\mathcal{F}_{i}, Y=b_{j}\right)$

$p_{i}=P(X=$ 央 $)$

$q_{j}=P\left(X=b_{j}\right)$

Hypotheses:

$H_{0}$ : there is no significant correlation between property incomes and social contributions

$H_{1}$ : there is significant correlation between property incomes and social contributions

$H_{0}: p_{i j}=p_{i *} q_{j}$ for each $i$ and $j$

$H_{1}:$ there are $i, j$ such $\operatorname{asp}_{i j} \neq p_{i}{ } q_{j}$

If the $H_{0}$ hypothesis is proved then $H \approx \chi^{2}((r-1) *(s-1))$,

otherwise $H \neq \chi^{2}((r-1) *(s-1))$. 


\section{Results and discussion}

Based on the recommendations of numerous authors we made the analysis of the dependence between the property incomes and the social contributions. First of all, Chao \& Eden (2002) referred to the significance of this analysis. Different tax rates leads to the differences in absolute amount and in share of property incomes (French, 2011). For this reason is needed a more detailed analysis of government revenues and the adoption of adequate policies in order to harmonize tax rates and the entire tax system. (Sinclaire, 2014). Williams (2019) came to the similar conclusions. Before a more detailed statistical analysis, the next two graphs shows the participation of property incomes and social contributions in total government revenues. Harmonization of property tax will also have a positive effect on investment activity (French, 2019).

Figure 1. Share of property incomes in total government revenues in selected countries

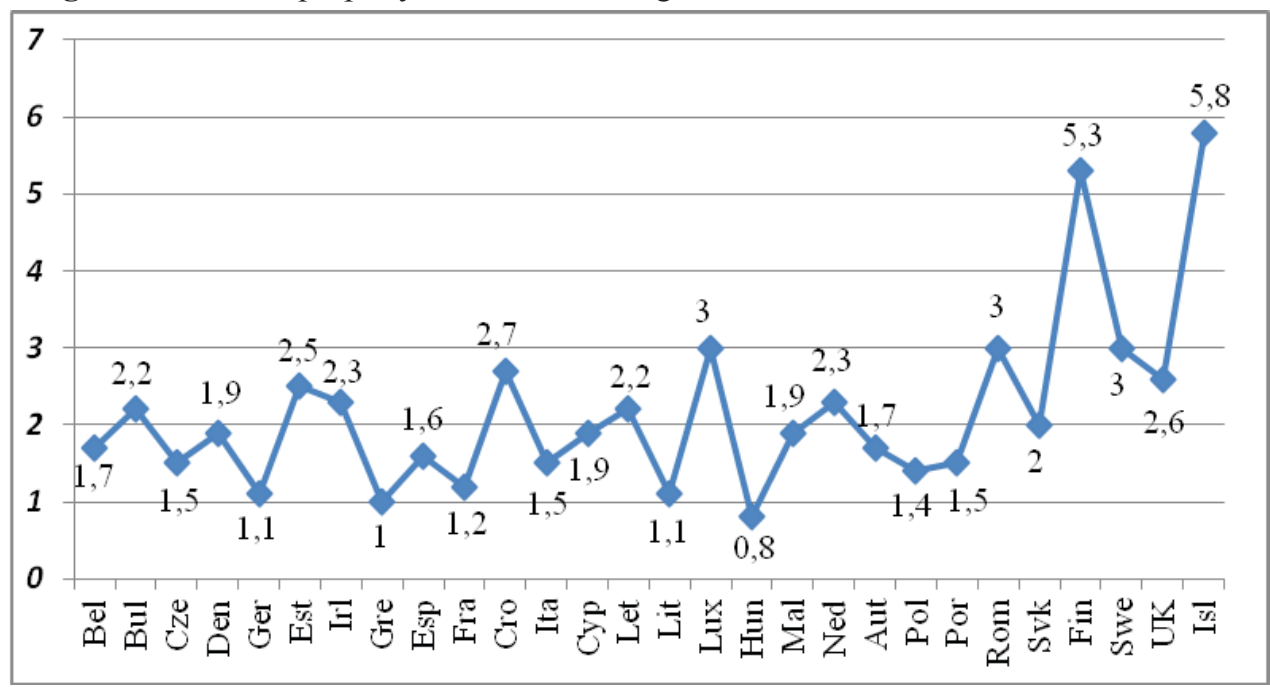

Source: Authors' calculations based on data used from Eurostat

Insight into Figure 1 is obviously different shares of property incomes in total government revenues. The country with the lowest share is Hungary with $0.8 \%$ and it is the only state with a share less than $1 \%$. In the group of countries with share within the limits (1-2)\% are Belgium (1.7\%), Czech Republic (1.5\%), Denmark (1.9\%), Germany (1.1\%), Greece, Spain (1.6\%), France (1.2\%), Italy (1.5\%), Cyprus (1.9\%), Lithuania (1.1\%), Malta \%), Austria (1.7\%), Poland (1.4\%), Portugal (1.5\%). A total of 14 countries, or $50 \%$ of the listed in the table, have shares in these bonderies.

Setting the share within limits $(2-3) \%$ the list of countries with this share is shorter. Bulgaria $(2.2 \%)$, Estonia (2.5\%), Ireland (2.3\%), Croatia (2.7\%), Latvia (2.2\%), Luxembourg (3.0\%), Netherlands (2.3\%), Ruminia (3.0\%), Slovakia (2.0\%), Sweden (3.0\%), United Kingdom (2.6\%). A total of 11 countries have share in the mentioned bonderies. More than 3\% of the share can be found in Finland (5.3\%) and in Iceland (5.8\%). It should be mentioned the case of Norway where the share of property incomes is dominant with share of $22.1 \%$ in total government revenues. 
Social contributions are the subject of researches by numerous authors, which inspired this article. More than 50\% of social contributions to workers' salaries are borne by employees. (Ooghe et al., 2013). Beside this conclusion, another one has imposed, that it will be necessary to increase the contribution rates if the level of pensions wants to be maintained. For this reason, they proposed establishing links between the categories of government revenues in order to make more effective the measures adopted by the policies. Legislation that would align social contributions and property incomes does not exist and it is therefore necessary to examine the connection of not only these categories but others in the structure of government revenues (Ramić \& Mešanović, 2017). The necessity of harmonizing the system of collecting social contributions as well as the necessary role of the state in solving this problem is crucial as well as determining the dependence among categories of government revenues (Ross, 2004).

Figure 2. Share of social contributions in total government revenues in selected countries

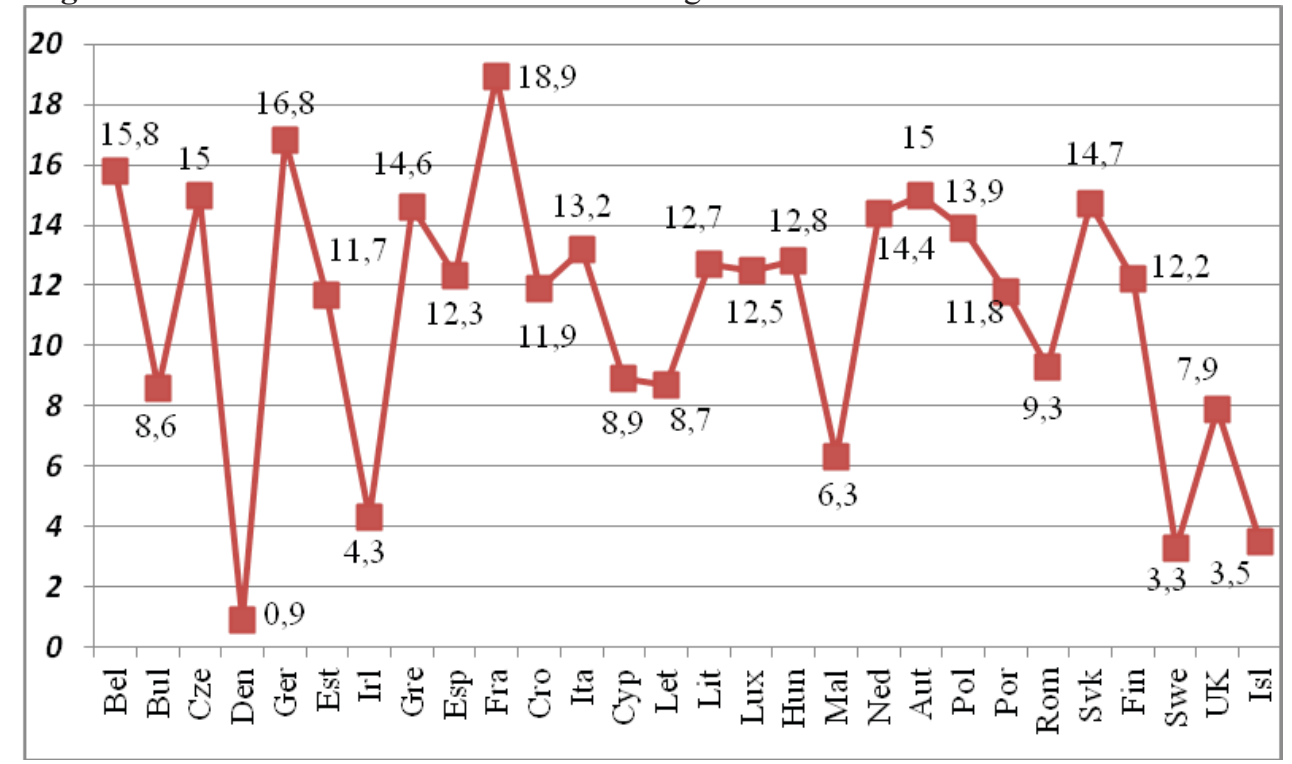

Source: Authors' calculations based on data used from Eurostat

Significant deviations in the share of social contributions in total government revenues is fact that provides data from Figure 2. In order to facilitate transparency and comparison countries are separated in two groups. The first group includes countries with participation of social contributions within the limits (1-10)\% of total revenues. This group of countries includes Bulgaria (8.6\%), Ireland (4.3\%), Cyprus (8.9\%), Latvia (8.7\%), Malta (6.3\%), Romania (9.3\% \%), Sweden (3.3\%), United Kingdom $(7.9 \%)$, Iceland $(3.5 \%)$ and in the end it has to be especially mentioned example of Denmark as the only state with share of social contributions below $1 \%$, which puts it at the last place of the listed countries, and the gap between Denmark and Sweden, which is 2 nd state with the lowest share of social contributions, is high. 
In the next group of countries we can include those with share above $10 \%$ of total government revenues. This group is more numerous because that most countries have more than $10 \%$ share of social contributions. Using data from Figure 2 those are Finland (12.2\%), Norway (10.4\%), Slovakia (14.7\%), Portugal (11.8\%), Poland (13.9\%), Austria (15.2\%), Netherlands 14.4\%), Hungary (12.8\%), Luxembourg (12.5\%), Lithuania (12.7\%), Italy (13.2\%), Croatia (11.9\%), France (18, 9\%), Spain (12.3\%), Greece (14.6\%), Estonia (11.7\%), Germany (16.8\%), Czech Republic (15.0\%) and Belgium (15.8\% ). It is obvious that the most developed countries have the largest share of social contributions, but the important question is who is responsible for these contributions, employees or employers (Noronha, et al., 2018)? Rates are different and vary widely, which confirms the fact that different rates apply in the countries (David, 2009). Once again, there is a request to harmonize and determine the dependencies between property incomes and social contributions based on the recommendations of numerous authors, which will prove or disprove it. That will show the degree of development of budget policy and propose measures and instruments in order to achieve basic macroeconomic goals. However, one thing should have be in mind, that the absolute alignment of budgetary policies can not be expected because of the great diversity of the economies (Wang \& Ge, 2018). For this reason, the harmonization and synchronization of tax systems with public expenditures and public revenues is very difficult to achieve (Peters, 2002).

Chi-squared test was used to examine the dependence of property incomes and social contributions. Preliminary analyzes of the normal distribution and homogeneity of variances have been done in order to analysis be justified. This analysis in the case of a chi-squared test is not necessary, but it certainly has given positive results because the data follows the normal distribution.

Table 1. Results of Chi-squared test with successive roots removed

\begin{tabular}{|c|c|c|c|c|c|}
\hline Canonical $\boldsymbol{R}$ & Canonical $\boldsymbol{R}$-sqr & Chi-sqr. & $\boldsymbol{d f}$ & $\boldsymbol{p}$ & Lambda Prime \\
\hline 0.155 & 0.024 & 0.673 & 1 & 0.411 & 0.975 \\
\hline
\end{tabular}

Source: Authors' representation based on SPSS

As already emphasized, two hypotheses have been tested.

$H_{0}$ : there is no significant correlation between property incomes and social contributions $H_{1}$ : there is significant correlation between property incomes and social contributions

The obtained results and the coefficient $p=0.411$, indicates that there is no significant correlation between property incomes and social contributions, which accepts $H_{0}$, and rejects the alternative $H_{1}$ hypothesis that presupposes the dependence of these variables. 
Table 2. Canoncial analysis summary (Spreads Canonical R: 0,155)

\begin{tabular}{|c|c|c|c|}
\hline & No. of vars. & Variance extracted & Total redundancy given the other set \\
\hline Left set & 1 & $100 \%$ & 2.418 \\
\hline Right set & 1 & $100 \%$ & 2.418 \\
\hline
\end{tabular}

Source: Authors' representation based on SPSS

The obtained results and the acceptance of the $\mathrm{H}_{0}$ hypothesis can be used for further conclusions. The need for harmonization of tax rates has been emphasized by many authors. Measures of implemented policies would be much easier to analyse in that case. The importance of agro-budgetary policy has been emphasized several times. Its necessity refers to developed countries as well as those in transition. The obtained results of property incomes and social contributions can be also interpreted as follows. Testing hypotheses that were set up at the beginning of the research can be concluded that the budget mechanism and the management of macroeconomic agro-budgetary policies are almost rudimentary in the domain of property incomes and that this mechanism should be perfected by a whole range of efficient instruments in countries where the public sector fiscal policy is more pronounced than the public debt in terms of social contributions.

\section{Conclusion}

Macroeconomic agro-budgetary policy is extremely scientifically challenging for all developed economies, but also for the economies in transition. In the synchronization and harmonization efforts of the overall budget policy, the state needs, through fiscal reforms, to make the necessary synchronization of measures and instruments of the public sector and its activities in the process of creating a unique macroeconomic space. These efforts are particularly characteristic of the system of creating a competitive market in order to allow freedom of movement of goods, money, labor and capital. The creation of such a market also prefers the countries that are in the transition process, including the Republic of Serbia. There are numerous studies on the property incomes and social contributions presented in the literature review. The conclusions reached by the authors concern the importance of all categories of government revenues and expenditures. The recommendations of many authors are focused on the require to explore the dependence of these categories and the importance of harmonizing tax rates at all levels. The inspiration for this topic has just emerged from these recommendations. The data clearly indicate the different shares of property incomes in total government revenues, which is a confirmation not only of the absence of harmonization of this type of tax, but of others that make up the structure of government revenues. In the discussion section, these differences are explained more detail. The situation is similar the social contributions whose detailed interpretation is given in the same part. To test the dependence, a Chi-squared test was used, and even preliminary analyzes of the normality and homogeneity of the variances were made, although it was not necessary. The obtained results confirmed the $\mathrm{H}_{0}$ hypothesis and rejected the alternative $\mathrm{H}_{1}$. 
The obtained results can also be used to make conclusions about the budget and agrobudget policy itself. Testing hypotheses that were set up at the beginning of the research can be concluded that the budget mechanism and the management of macroeconomic budgetary and thus agro-budgetary policies are almost rudimentary in the domain of property incomes and that this mechanism should be perfected by a whole range of efficient instruments in countries where the public sector fiscal policy is more pronounced than the public debt in terms of social contributions. Regardless of the absence of the significant results in harmonization of tax rates, it should be said that efforts still exists. It can be discussed about its dynamics, but the fact of its existence is obvious. The European Union, as a concept of a modern state, tends to do so, but the obstacles are numerous and they are mainly based on the legal regulations of the member states and the jurisdiction that is different in the countries. Since the moment of submitting a request for a change in tax policy and tax rates, to the adoption, a lot of time passes with the inevitable political factor and the interests of the ruling classes. However, it should strive to implement measures and policy instruments in transition countries, which will make the accession processes to the European Union significantly faster and open access to various funds in order to achieve faster economic development. All this can be an inspiration to future authors to expand the research and enrich them with new conclusions.

\section{Conflict of interests}

The authors declare no conflict of interest.

\section{References}

1. Anderson, J. \& Schimul, S. (2018). State and local property, income, and sales tax elasticity: Estimates from dynamic heterogeneous panels, National Tax Journal, 71(3): 521-546 doi: https://doi.org/10.17310/ntj.20183.04

2. Andrei, J. V., Mieila, M., \& Panait, M. (2017). The impact and determinants of the energy paradigm on economic growth in European Union. PloS one, 12(3), doi: https://doi.org/10.1371/journal.pone.0173282

3. Auerbach, J., \& Feenberg, D. (2000). The Significance of Federal Taxes as Automatic Stabilizers, Journal of Economic Perspectives, 14(3): 37-5. doi: https:// doi.org/10.1257/jep.14.3.37

4. Baum, A., Baum, C.M., Nunnington, N., \& Mackmin, D. (2013). The Income Approach to Property Valuation, London

5. Benito, B., Brusca, I., \& Montesino, V. (2017). The harmonization of government financial informationsystems: the role of the IPSASs, International Review of AdministrativeSciences 73(2):293-317 doi: https://doi.org/10.1177/0020852307078424

6. Chao, C.C., \& Eden, S.H. (2002). On property tax coordination, Journal of Real Estate Finance and Economics, 25(1): 67-79 doi: http://dx.doi.org/10.1023/A:1015324801791 
7. David, N. (2009): Efficiency aspects of increasing inheritance taxes while decreasing income taxes, Applied Economics, 41(26): 3359-3366, http://dx.doi. org/10.1080/00036840701416411

8. Dimitrijević, M. (2018). Relevantna obeležja savremenog javnog finansiranja. Zbornikradova Pravnogfakulteta u Nišu, 57(81): 103-118. [in English:Dimitrijević, M. (2018). Relevant features of contemporary public financing. Zbornik radova Pravnog fakulteta u Nišu, 57(81), 103-118.].

9. Fatima, G., Ahmed, M., \& Ur Rehman, W. (2012). Consequential Effects of Budget Deficit on Economic Growth of Pakistan, International Journal of Business \& Social Science,3(7): 203-208

10. French, N. (2011), "The Income Approach to Property Valuation (6th edition)", Journal of Property Investment \& Finance, 29(6): 714-715 doi: https://doi. org/10.1108/jpif.2011.29.6.714.1

11. French, N. (2019). "Property investment: gearing and the equity rate of return", Journal of Property Investment \& Finance, 37(3): 323-328. doi: https://doi. org/10.1108/JPIF-02-2019-0011

12. Goudswaard, K., \& Caminada, K. (2015). Social security contributions: economic and public finance considerations, International Social Security Review, 68(4): 25 45 doi: $\underline{\text { http://dx.doi.org/10.1111/issr.12086 }}$

13. Grover, R. (2018), "Betterment: a taxing problem”, Journal of Property Investment \& Finance, 36(2): 217-226. doi: https://doi.org/10.1108/JPIF-06-2017-0046

14. Harjula, M.(2007). A guide to Europen Union funding for NGOs, Tony Venables, Aleksandar Resanović, European Action Citizen Service, Brussels, Center for peace Democracy Development, Belgrade.

15. Kovačević, M., Trandafilović, J., \& Kalač, D. (2019). Revizijski aspekt izvršenja budžeta, Oditor - časopis za Menadžment, finansije i pravo, 5(1): 93-105. doi: https:// doi.org/doi:10.5937/Oditor1901091K [in English: Kovačević, M., Trandafilović, J., \& Kalač, D. (2019). Audit aspect of execution of the budget. Oditor - Journal of Management, Finance and Law, 5(1), 93-105.].

16. Lind, H., \& Nordlund, B. (2019)."The concept of market value in thin markets and its implications for international accounting rules (IFRS)", Journal of Property Investment \& Finance, 37(3): 301-310. doi: https://doi.org/10.1108/JPIF-02-2019$\underline{0022}$

17. Mićović S., Miletić J. (2019). Poslovni subjekt kao osnova održivosti razvoja. Održivi razvoj, 1(1), 41-49. [in English: Mićović S., Miletić J. (2019). Business entity as a basis for sustainability of development. Sustainable Development, 1(1), 41-49.].

18. Milojević, I., Mihajlović, M., \& Cvijanović, M. (2012). Impact of organizational failure of relevance consolidated budget. Ekonomika poljoprivrede, 59(1): 63-71. 
19. Milojević, I., \& Mihajlović, M. (2019). Primena metoda ocene investicionih projekata u javnom sektoru. Oditor - časopis za Menadžment, finansije i pravo, 5(1), 19-31. [in English: Milojević, I., \& Mihajlović, M. (2019). Implementation of the method of assessing investment projects in the public sector. Oditor - časopis za Menadžment, finansije i pravo,5(1), 19-31.].

20. Nearing, S. (2019). Service income and property income, Taylor \& Francis, Ltd. on behalf of the American Statistical Association, 14(107): 236-259

21. Neary, B., Horák, J., Kovacova, M., \& Valaskova, K., (2018). The future of work: Disruptive business practices, technology-driven economic growth, and computer-induced job displacement. Journal of Self-Governance and Management Economics, 6(4), 19-24. doi: https://doi.org/doi:10.22381/JSME6420183

22. Neumann, M. (1986). Changes in revenue structures from the point to view of political economy, Internacional institute of public finance, $42^{\text {nd }}$ congress, Atheness, 20-25 august. pp. 5-7.

23. Nica, E. (2018). Gig-based working arrangements: Business patterns, labormanagement practices, and regulations. Economics, Management, and Financial Markets, 13(1), 100-105.

24. Noronha, C., Guan, J., \& Fan, J. (2018). Firm value and social contribution with the interaction of corporate governance : Social contribution value per share, Sustainability Accounting, Management and Policy Journal, 9(2): 165-200. doi: https://doi.org/10.1108/SAMPJ-10-2016-0078

25. Ooghe, E., Schokkaert, E., \& Flechet, J. (2003). The Incidence of Social Security Contributions: An Empirical Analysis, Empirica, 30(1): 81-106 doi: http://dx.doi. org/10.1023/A:102412143204

26. Pedauga, L., Velazques, A., \& Bueno, M. (2018). Property income from-whom-towhom matrices: A dataset based on financial assets-liabilities stocks of financial instrument for Spain, Data in Brief, 19(1): 449-455. doi: https://doi.org/10.1016/j. dib.2018.05.018

27. Peters, G.B. (2002). The Politics of Taxation, Blackwell, Cambridge. pp. 95-97 doi: http://dx.doi.org/10.3138/cjh.39.3.623

28. Pop, A. (2016). The influence of social contributions of the economic growth, Economic Science, 25(1): 397-401 doi: https://doaj.org/article/1a7eedd581114eaab03 b9389167f9aa6

29. Popescu, G. H., Petrescu, I. E., \& Sabie, O. M. (2018). Algorithmic labor in the platform economy: digital infrastructures, job quality, and workplace surveillance. Economics, Management and Financial Markets, 13(3), 74-79. doi: http://dx.doi.org/10.22381/EMFM13320184

30. Radovanović, V., Rendulić, G. (2017). With knowledge and innovation in new tourism venture, Hotel and Tourism Management, 5(2), 96-105. 
31. Ramić, M. \& Mešanović, M. (2017). Gap calculation of income tax and social contributions among entities and Brcko district, Business Consultant, 9(68): 85-92

32. Ross, S. (2004). Collection of social contributions: Current practice and critical issues, International Social Security Association

33. Sekera, J. (2018). Missing from the mainstream: the biophysical basis of production and the public economy. Economics, Management, and Financial Markets, 13(3), 56-73 doi: http://dx.doi.org/10.22381/EMFM13320183

34. Simić, N., Kosumi, T., \& Jialiang, Y. (2019). Regulatorni instrumenti održivog razvoja, Održivi razvoj, 1(1): 15-26. [in English: Simić, N., Kosumi, T., \& Jialiang, Y. (2019). Sustainable Development Regulatory Instruments, Sustainable Development, 1(1): 15-26.].

35. Sinclaire, W. (2014). Income from land and property, Fiscal Services Ltd 2014, 42-44.

36. Shang, Q., Liu, W. H., \& Yin, Y. (2018). The Impact of within-Household Relative Income on Happiness: Does Gender Identity Matter?. Journal of Research in Gender Studies, 8(2).

37. Van Horne, J., \& Wachowicz, J. (2007). Fundamentals of financing management, Data status, Beograd.

38. Vukša, S., Anđelić, D., \& Kolarski, I. (2015). Uloga ekonomske politike u ekonomskim krizama, Oditor - časopis za Menadžment, finansije i pravo, Beograd, 3(12): 4-12 doi: http://dx.doi.org/10.5937/Oditor1512013V [in English: Vukša, S., Anđelić, D., \& Kolarski, I. (2015). The Role of Economic Policy in Economic Crises, Oditor - Journal of Management, Finance and Law, 3(12): 4-12].

39. Wang, Y., \& Ge, Y. (2018). The effect of family property income on labor supply: Evidence from China, International Review of Economics and Finance, 1(57): 114121. doi: https://doi.org/10.1016/j.iref.2018.02.016

40. Williams, J.H. (2019). "Property and income" Tax, The Assurance Magazine, and Journal of the Institute of Actuaries, 3(2): 168-169 doi: http://dx.doi.org/10.1017/ s2046165800020931 